\title{
Detrital subsidy from subtidal kelp beds is altered by the invasive green alga Codium fragile ssp. fragile
}

\author{
Kira A. Krumhansl* ${ }^{*}$ Robert E. Scheibling \\ Department of Biology, Dalhousie University, Halifax, Nova Scotia B3H 4J1, Canada
}

\begin{abstract}
Invasive species have the potential to alter the dynamics of detrital subsidy from high to low productivity areas through changes in quantity and nutritional quality of detrital material. We examined the effect of the invasive alga Codium fragile ssp. fragile on the nature of detrital export from subtidal algal beds off Nova Scotia, Canada, by comparing changes in mass, nutritional quality $(\% \mathrm{C}, \% \mathrm{~N}, \mathrm{C} / \mathrm{N}$ ratio), concentration of dimethylsulfoniopropionate (DMSP, a secondary metabolite that deters grazers), and isotopic composition $\left(\delta^{13} \mathrm{C}\right.$ and $\left.\delta^{15} \mathrm{~N}\right)$ between $C$. fragile and the native kelp Saccharina latissima at $4 \mathrm{wk}$ intervals over $16 \mathrm{wk}$ of degradation in cages on a sand bottom at $19 \mathrm{~m}$ depth. $C$. fragile degraded more slowly, and had a consistently lower $\mathrm{C} / \mathrm{N}$ and higher DMSP concentration, than $S$. latissima. Isotope signatures did not differ between algal species: $\delta^{15} \mathrm{~N}$ became slightly enriched $(\sim 1 \%)$ after 16 wk of degradation, with no change in $\delta^{13} \mathrm{C}$. We also compared macrofaunal communities associated with degrading thalli of each algal species and found significantly higher abundances of invertebrates (mainly capitellid polychaetes) on $S$. latissima after 8 wk of degradation, resulting in lower evenness $\left(J^{\prime}\right)$ and diversity $\left(H^{\prime}\right)$ on $S$. latissima compared to $C$. fragile. Macrofaunal community composition became similar between algal species at 12 and 16 wk in concordance with decreases in C/N ratio in S. latissima and DMSP concentration in $C$. fragile. Our results indicate that differences in biochemical composition and the rate of degradation between $C$. fragile and native kelps result in community-level effects in areas linked to shallow algal beds via the transfer of detritus.
\end{abstract}

KEY WORDS: Codium fragile $\cdot$ Kelp $\cdot$ Degradation $\cdot$ Invasive species $\cdot$ Detritus $\cdot$ Stable isotopes

\section{INTRODUCTION}

The transfer of organic detritus from highly productive macroalgal beds to adjacent habitats can be an important trophic linkage (Duggins \& Simenstad 1989, Bustamante et al. 1995, Bustamante \& Branch 1996, Britton-Simmons et al. 2009), particularly if local productivity in the recipient community is low or of poor nutritional quality (Tenore \& Hanson 1980, Bouillon et al. 2002, Wernberg et al. 2006). The supply of allochthonous material can represent a substantial energy subsidy in these situations, influencing patterns of community organization and secondary production (Bustamante et al. 1995). Invasive species have the potential to alter trophic connected- ness by changing the species composition, productivity, and biomass of macroalgal assemblages and, in turn, the quantity and quality of exported detrital material (Krumhansl \& Scheibling 2011).

Large quantities of detritus are produced from subtidal kelp beds annually through continuous erosion and fragmentation of blades and dislodgement of thalli (Chapman 1984, Tala \& Edding 2007, Krumhansl \& Scheibling 2011). This material can be transported inshore or alongshore to low-energy habitats at shallower or similar depths, or offshore to deeper sedimentary or rocky habitats with low local productivity (Chapman 1981, Mann 1982, Scheibling et al. 1999). Sea urchins can locate, trap, and rapidly consume algal detritus as it is transported or 
deposited in deeper waters (Vetter \& Dayton 1999, Britton-Simmons et al. 2009). Where sea urchins are absent, however, deposits of detrital kelp may accumulate and remain on the order of months to years (Tzetlin et al. 1997, Vetter \& Dayton 1998, FilbeeDexter \& Scheibling 2012), degrading slowly and being consumed by other macrofauna.

The green algal genus Codium has a broad geographic distribution and $C$. fragile ssp. fragile (formerly tomentosoides, Provan et al. 2008, hereafter $C$. fragile) is among the most invasive algal species worldwide (Carlton \& Scanlon 1985, Trowbridge 1998). C. fragile was first introduced to Nova Scotia, Canada, in the late 1980s (Bird et al. 1993) and had spread along the entire Atlantic coast by 2007, forming monospecific meadows or mixed stands with native kelps (Chapman et al. 2002, Watanabe et al. 2010). In the NW Atlantic, C. fragile fragments in the fall and is dislodged from the substratum during winter storms (Begin \& Scheibling 2003, D'Amours \& Scheibling 2007). Large mats of drifting thalli and branched fragments of $C$. fragile have been observed in shallow sedimentary areas adjacent to dense stands of the alga; these mats can persist for months before they are transported offshore during storms (Watanabe et al. 2009). The effects of $C$. fragile on community dynamics have been well documented both within kelp beds (Scheibling \& Gagnon 2006, Schmidt \& Scheibling 2006, 2007) and in intertidal habitats (Jones \& Thornber 2010, Lutz et al. 2010), but the fate of detrital fragments of $C$. fragile is unknown.

Macrophyte tissues usually have a high content of indigestible fibrous carbon and low contents of nitrogen and protein, which limits their nutritional value to most herbivores (Mann 1988). Consequently, much of the primary production from macrophyte assemblages, such as kelp beds and seagrass meadows, enters detrital pathways rather than being directly grazed (Mann 1988, Cebrian 1999). Macrophyte detritus is colonized by microbes that break down refractory carbon and draw in nitrogen from seawater, thereby increasing the nutritional value and facilitating consumption by a wider variety of consumers (Mann 1988). The rate of degradation is therefore largely dependent on the extent of microbial colonization and transformation and varies among macrophyte phyla (Tenore \& Hanson 1980). Consumption of live macrophyte tissues may be restricted by secondary metabolites, such as phlorotannins found in high concentrations in kelps and other brown algae (Johnson \& Mann 1986, Paul 1992, Iken et al. 2009). Phlorotannins break down as kelp degrades (Norderhaug et al. 2003), increasing the palatability of kelp for detritivores. Dimethylsulfoniopropionate (DMSP) is another secondary metabolite found in all macroalgal phyla, with highest concentrations in green algae (Van Alstyne \& Puglisi 2007). DMSP is produced, and cleaved into dimethylsulfide (DMS) and acrylic acid, as an activated defense against herbivory (Van Alstyne et al. 2001, Van Alstyne \& Houser 2003, Lyons et al. 2010). DMSP occurs in high concentration in Codium fragile and varies seasonally in response to changing water temperature and light intensity (Lyons et al. 2007, 2010). Like phlorotannins in kelps, concentration of DMSP may decrease during degradation of $C$. fragile, but this has not been examined.

Stable isotope ratios of $\mathrm{C}$ and $\mathrm{N}$ are widely used to track the flow of organic matter from primary producers to consumers in marine food webs (Peterson \& Fry 1987). Microbial degradation can affect these isotopic ratios in algal tissues, although this has only been examined for a few species of marine macroalgae (Stephenson et al. 1986, Fenton \& Ritz 1988, Hill $\&$ McQuaid 2009). In food webs where most of the primary production enters detrital pathways, degradation may obscure linkages based on isotopic signatures in live tissue, underscoring the importance of measuring changes in isotopic ratios during degradation of detritus.

In the present study, we examine the effect of Codium fragile on the nature of detrital export from shallow kelp beds by comparing changes in mass, nutritional quality and palatability, and isotopic composition between the invasive alga and native kelp Saccharina latissima (formerly S. longicruris, McDevit \& Saunders 2010) at 4 wk intervals over $16 \mathrm{wk}$ of degradation. To examine how changes in the quantity and nutritional quality of detrital material influence colonization by macrofauna, we concurrently measured changes in the macrofaunal assemblage associated with each algal species. These results improve our understanding of the dynamics of detrital subsidies from kelp beds and broaden our knowledge of the effects of invasive species beyond the habitats to which they have been introduced.

\section{MATERIALS AND METHODS}

\section{Experimental design}

The experimental site (The Lodge, $44^{\circ} 33^{\prime} 32.98^{\prime \prime} \mathrm{N}$, $64^{\circ} 01^{\prime} 56.75^{\prime \prime} \mathrm{W}$ ) is located near the mouth of a large semi-protected embayment, St. Margarets Bay, near 
Halifax, Nova Scotia, Canada. The rocky substratum consists of ledges and boulders that grade to sand at $\sim 17 \mathrm{~m}$ depth. Kelps (primarily Saccharina latissima, Laminaria digitata, and Agarum cribosum) form a dense canopy, which peaks in cover from May to July and declines from October to December (Krumhansl \& Scheibling 2011). Codium fragile is interspersed with kelps, following a similar seasonal pattern in abundance (Schmidt \& Scheibling 2005). Sandy substrata below the limit of boulders and ledges are devoid of attached fleshy macroalgae but periodically accumulate deposits of drift algae (K. FilbeeDexter \& R. E. Scheibling unpubl. data). Our experiment was conducted from 9 August to 29 November 2010 to coincide with seasonal decreases in the biomass of kelps and $C$. fragile in the shallow subtidal zone.

To measure changes in biochemical properties of algal tissues and colonization by macrofauna during degradation, we placed thalli of Codium fragile or Saccharina latissima into nylon-mesh $(0.5 \mathrm{~cm}$ aperture) bags that were placed within plastic cages $(33 \times$ $33 \times 27 \mathrm{~cm}, 2.5 \mathrm{~cm}$ aperture) anchored to the sandy seabed at $19 \mathrm{~m}$ depth. Large thalli of S. latissima (100 to $200 \mathrm{~cm}$ total length) and $C$. fragile $(50$ to $75 \mathrm{~cm}$ ) without visible signs of degradation or heavy colonization by epibionts were haphazardly collected using SCUBA from the algal bed at 5 to $7 \mathrm{~m}$ depth. Thalli were cleaned of any epibionts, air dried for $1 \mathrm{~min}$, and weighed into $500 \mathrm{~g}$ (0.001 g precision) batches that mimicked small deposits of drift algae. These were loosely packed in labeled mesh bags $(40 \times 50 \mathrm{~cm}, 0.5 \mathrm{~cm}$ aperture), with 12 replicate bags per algal species, and kept in seawater until delivery to the seabed by divers. Bags were randomly allocated to 24 numbered cages that were anchored to the sand bottom and spaced at $1.5 \mathrm{~m}$ intervals along a single linear array running parallel to and approximately 4 to $6 \mathrm{~m}$ away from the lower margin of the algal bed. There were 3 replicates of each combination of 4 levels of time $(4,8,12$, or 16 wk of degradation) and 2 levels of species (S. latissima, C. fragile) in this factorial, completely randomized design. At each time interval, replicate bags of each algal species $(\mathrm{n}=$ 3) were collected and transported in coolers to the laboratory, where they were placed in flow-through seawater tanks and processed within $3 \mathrm{~h}$. The mesh bags remained on the sediment surface throughout the experiment (i.e. were not buried), although some sedimentation occurred within bags as a result of reduced flow.

Temperature was measured at 30 min intervals at the experimental array using a HOBO pendant data

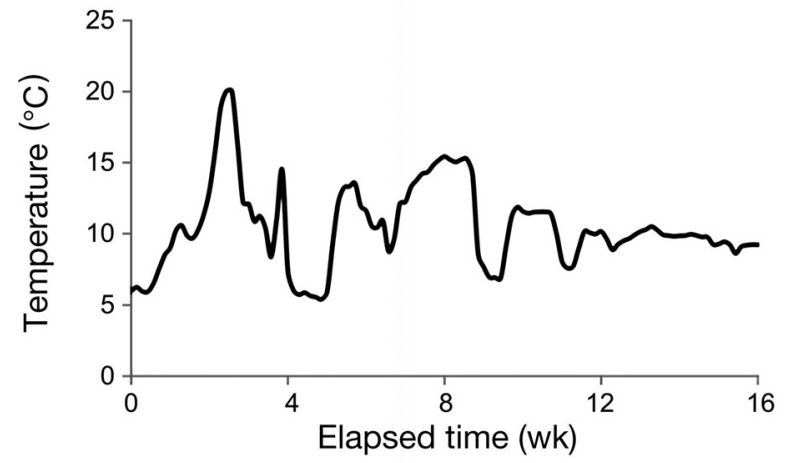

Fig. 1. Average daily temperature $\left({ }^{\circ} \mathrm{C}\right)$ at the experimental array (19 m depth) over the 16 wk experimental period (9 August to 29 November 2010)

logger (Onset Computer Corp.). Temperature was highly variable during the first $12 \mathrm{wk}$ of the experimental period, ranging from 5.5 to $20.0^{\circ} \mathrm{C}$, then stabilized over the last 4 wk (Fig. 1). Mean temperature during each sampling interval was relatively constant, ranging from 9.6 to $11.2^{\circ} \mathrm{C}$.

\section{Sample processing and analyses}

In the laboratory, the algal sample in each bag was cleaned of epibionts and weighed. Macrofauna (body size $>1 \mathrm{~mm}$ ) on each algal sample or in the respective mesh bag were placed directly into $70 \%$ ethanol and identified (to the lowest taxonomic level possible) using a dissecting microscope. A section of each sample was rinsed in distilled water and dried at $60^{\circ} \mathrm{C}$ for $48 \mathrm{~h}$ until constant weight. Dried algal samples were ground to a fine homogeneous powder using a mortar and pestle and weighed into tin capsules and shipped to the Stable Isotopes in Nature Laboratory at the University of New Brunswick (Saint John, New Brunswick, Canada) for $\mathrm{C}$ and $\mathrm{N}$ content and isotopic $\left(\delta^{13} \mathrm{C}, \delta^{15} \mathrm{~N}\right)$ analysis. The isotopic value of each sample is reported in $\delta$ notation as:

$$
\delta X(\%)=\left(R_{\text {sample }} / R_{\text {standard }}-1\right) \times 1000
$$

where $\delta X=\delta^{13} \mathrm{C}$ or $\delta^{15} \mathrm{~N}$ and $R={ }^{13} \mathrm{C}:{ }^{12} \mathrm{C}$ or ${ }^{15} \mathrm{~N}:{ }^{14} \mathrm{~N}$. PeeDee belemnite and air were used as standards for $\mathrm{C}$ and $\mathrm{N}$, respectively.

A $1 \mathrm{~cm}^{2}$ section of each algal sample was placed in a $14 \mathrm{ml}$ glass vial containing $2 \mathrm{ml} 10 \mathrm{M} \mathrm{NaOH}$ at the sea surface immediately upon delivery from the seabed and crimped with a Pharma-fix septa (Graze Alltech). Sections of tissue were selected from the middle of a branch for Codium fragile and central 
region of a blade for Saccharina latissima. The vials were stored at room temperature in the dark to allow the DMS in each sample to equilibrate with the vial headspace. Samples were analyzed for both intracellular DMS and DMSP, collectively termed DMS(P). Then, $100 \mu \mathrm{l}$ (S. latissima) or $10 \mu \mathrm{l}$ (C. fragile) of vial headspace was analyzed by gas chromatography using a Shimadzu 2014 gas chromatograph fitted with a $25 \mathrm{~m}$ capillary column (Restek RTx-5MS, $0.25 \mathrm{~mm} \mathrm{ID)} \mathrm{and} \mathrm{sulfur-specific} \mathrm{flame}$ photometric detector (FPD) at the University of Glasgow, UK (injector port and column oven temperature, $45^{\circ} \mathrm{C}$; detector temperature, $200^{\circ} \mathrm{C}$ ). DMS peak retention time was $\sim 1.5 \mathrm{~min}$. Sample concentrations were quantified from DMSP standard calibration curves (DMSP standard from Research Plus Inc.), and normalized by sample dry weight (g). The limit of detection was $960 \mathrm{ng} \mathrm{S}$ per $100 \mu \mathrm{l}$ injection (headspace); standard and sample precision was within $3 \%$.

\section{Statistical analyses}

The effect of algal species (Saccharina latissima or Codium fragile) and elapsed time (fixed factors) on the mass (4 to $16 \mathrm{wk}$ ) and biochemical properties of algal tissues (0 to $16 \mathrm{wk}$ ) was analyzed using a 2-way analysis of variance (ANOVA), except for DMS(P) concentration which was analyzed using 1-way ANOVA for C. fragile only. Transplantation stress may have caused an increase in DMSP in the first $4 \mathrm{wk}$ of the experiment (Lyons et al. 2010); therefore, only 4 to 16 wk were included in this analysis. The abundance of associated macrofauna, and species richness, Pielou's evenness index $\left(J^{\prime}\right)$, and Shannon's diversity index $\left(H^{\prime}\right)$, were also compared between algal species and over time (4 to $16 \mathrm{wk}$ ) using a 2-way ANOVA. Post hoc tests (Tukey's honestly significant difference [HSD] test, $\alpha=0.05$ ) were used to identify patterns over time within each algal species. Wet mass and abundance data were $\log (x)$ transformed, and $\% \mathrm{C}$ and $\% \mathrm{~N}$ data were arcsine transformed to meet the assumptions of normality (ShapiroWilk's test, $\alpha=0.05$ ) and homogeneity of variance (Bartlett's test, $\alpha=0.05$ ). Evenness data were normally distributed, but variances were heterogeneous. Transformation of these data did not improve variance homogeneity, and untransformed data were used.

Permutational multivariate analysis of variance (PERMANOVA; Anderson 2001), based on Bray-
Curtis similarity matrices calculated from squareroot-transformed data, was used to examine the effect of algal species and elapsed time on macrofaunal composition. Homogeneity of multivariate dispersions was satisfied for community data grouped by algal species and elapsed time (permutational analysis of multivariate dispersions, $\mathrm{p}>0.05$; Anderson 2004). Cluster analysis was then used to determine similarities among samples. Taxa that most contributed to differences between algal species and among time intervals were identified using the similarities of percentages routine (SIMPER). The effects of algal species and elapsed time on the abundances of these taxa were analyzed using 2-way ANOVA. Macrofaunal abundance was $\log (x+1)$ transformed as required to meet the assumption of normality and homogeneity of variance. Multivariate analyses were conducted using PRIMER 6 software with the PERMANOVA+ package (Clarke \& Gorley 2006).

Table 1. Two-way ANOVA of the effect of algal species and elapsed time $(0,4,8,12$, and $16 \mathrm{wk})$ on the weight $(\mathrm{g}), \% \mathrm{C}$, $\% \mathrm{~N}, \delta^{13} \mathrm{C}$, and $\delta^{15} \mathrm{~N}$ of degrading algal samples. Tukey's pairwise comparisons were made where time was significant. Lines connect non-significant subsets of treatment means

\begin{tabular}{|c|c|c|c|c|c|}
\hline $\begin{array}{l}\text { Response } \\
\text { Factor }\end{array}$ & df & MS & $F$ & $\mathrm{p}$ & Pairwise \\
\hline \multicolumn{6}{|l|}{ Wet mass } \\
\hline Algae & 1 & 5.17 & 26.0 & $<0.001$ & \multirow{4}{*}{$\underline{4}{ }_{-}^{8} 1216$} \\
\hline Time & 3 & 4.57 & 23.0 & $<0.001$ & \\
\hline Time $\times$ Algae & 3 & 0.53 & 2.67 & 0.083 & \\
\hline Residual & 16 & 0.20 & & & \\
\hline \multicolumn{6}{|l|}{$\% \mathrm{C}$} \\
\hline Algae & 1 & 0.29 & 723 & $<0.001$ & \multirow{8}{*}{$\underline{048} \underline{1216}$} \\
\hline Time & \multicolumn{2}{|c|}{$4<0.01$} & 1.40 & 0.270 & \\
\hline Time $\times$ Algae & \multirow{2}{*}{\multicolumn{2}{|c|}{$\begin{aligned} 4 & <0.01 \\
20 & <0.01\end{aligned}$}} & 1.25 & 0.323 & \\
\hline Residual & & & & & \\
\hline \multicolumn{6}{|l|}{$\% \mathbf{N}$} \\
\hline Algae & \multicolumn{2}{|c|}{$1<0.01$} & 10.5 & 0.0041 & \\
\hline Time & \multicolumn{2}{|c|}{$4<0.01$} & 15.4 & $<0.001$ & \\
\hline Time $\times$ Algae & \multirow{2}{*}{\multicolumn{2}{|c|}{$\begin{aligned} 4 & <0.01 \\
20 & <0.01\end{aligned}$}} & 2.20 & 0.1056 & \\
\hline Residual & & & & & \\
\hline \multicolumn{6}{|l|}{$\delta^{13} \mathrm{C}$} \\
\hline Algae & 1 & 0.73 & 0.368 & 0.551 & \\
\hline Time & 4 & 2.00 & 1.01 & 0.425 & \\
\hline Time $\times$ Algae & 4 & 2.73 & 1.38 & 0.276 & \\
\hline Residual & 20 & 1.98 & & & \\
\hline \multicolumn{6}{|l|}{$\delta^{15} \mathbf{N}$} \\
\hline Algae & 1 & $<0.01$ & 0.0060 & 0.936 & \multirow{4}{*}{$0 \underline{\underline{4} 8 \underline{12} 16}$} \\
\hline Time & 4 & 0.99 & 5.42 & 0.004 & \\
\hline Time $\times$ Algae & 4 & 0.05 & 0.280 & 0.887 & \\
\hline Residual & 20 & 0.09 & & & \\
\hline
\end{tabular}



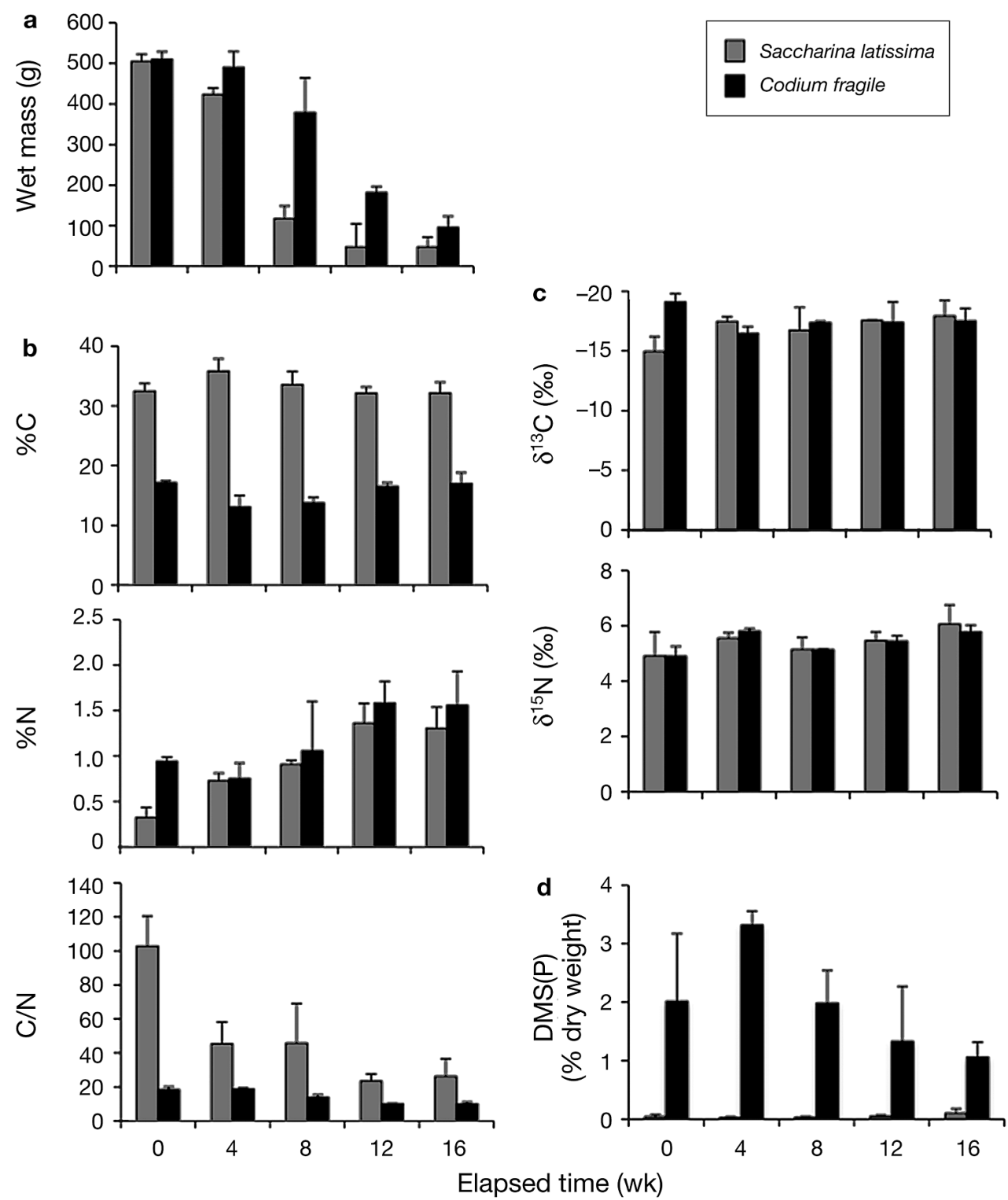

Fig. 2. Saccharina latissima and Codium fragile. (a) Wet mass (g), (b) \% C, \% N, C/N ratio, (c) $\delta^{13} \mathrm{C}(\%), \delta^{15} \mathrm{~N}(\%)$, and (d) dimethylsulfide and dimethylsulfoniopropionate, DMS(P), concentration (\% dry weight) of the 2 algal species at the start of the experiment and after 4, 8, 12, and 16 wk of degradation. Data are means $(+1 \mathrm{SD}, \mathrm{n}=3)$

\section{RESULTS}

\section{Changes in mass and biochemical composition}

The wet mass of both Saccharina latissima and Codium fragile decreased (Table 1, Fig. 2a) to 9.5 and $18.4 \%$ of initial mass after $16 \mathrm{wk}$, respectively. Mass loss of $S$. latissima was greatest between 4 and $8 \mathrm{wk}$ ( $63 \%$ decrease), while $C$. fragile showed a near linear decrease in mass between 4 and 16 wk. Carbon content of $S$. latissima $(32.0 \%$, averaged over all intervals) was approximately twice that of $C$. fragile
$(15.5 \%)$, and did not change significantly during degradation for either species (Fig. 2b, Table 1). Nitrogen content was significantly higher in C. fragile (1.18\% averaged over all intervals) than in S. latissima $(0.92 \%)$ and increased significantly in both species between 8 and 12 wk (Fig. 2b, Table 1). Consequently, the $\mathrm{C} / \mathrm{N}$ ratio of both algal species decreased during the $16 \mathrm{wk}$ of degradation, but this decrease was much greater for S. latissima (from 102.8 to 26.2) than for $C$. fragile (from 18.3 to 9.9) (Fig. $2 b) . \delta^{13} \mathrm{C}$ did not differ significantly between algal species or between sampling intervals (Fig. 2c, 

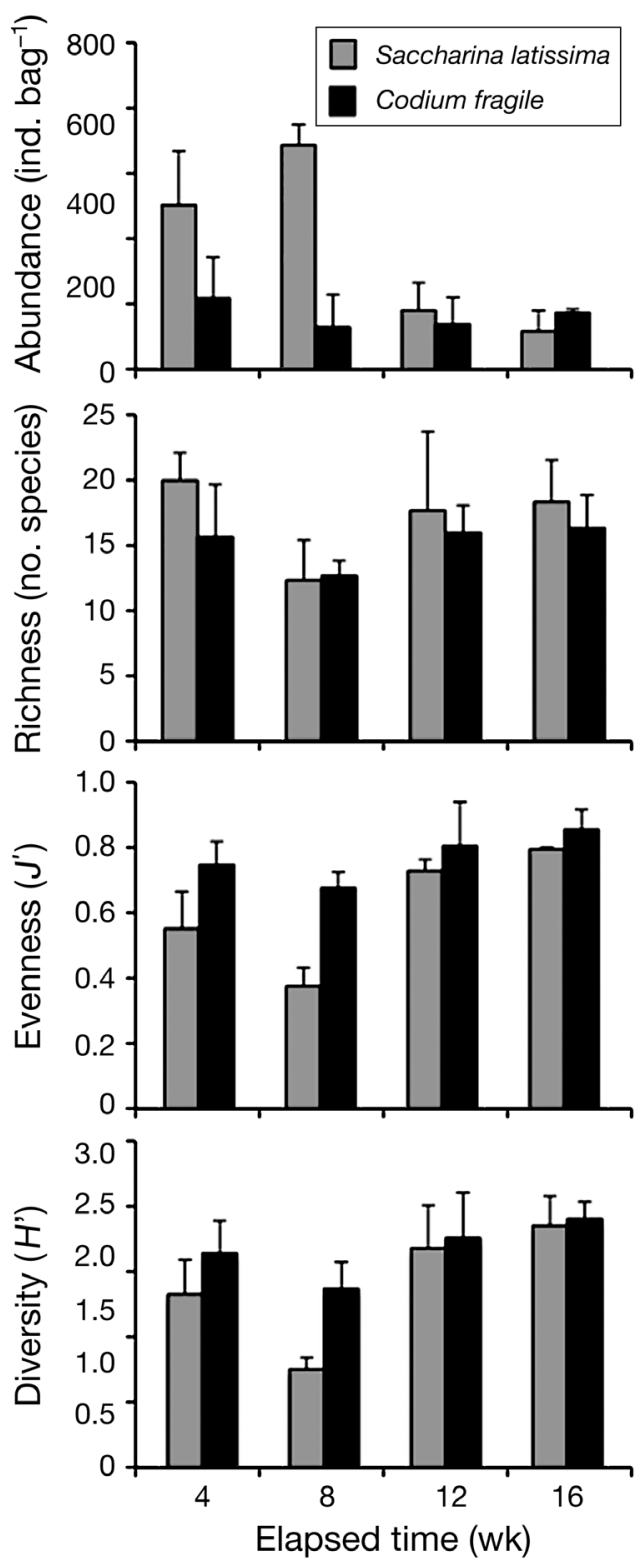

Fig. 3. Saccharina latissima and Codium fragile. The abundance (ind. bag $^{-1}$ ), richness (no. of species), evenness $\left(J^{\prime}\right)$, and diversity $\left(H^{\prime}\right)$ of macrofaunal communities associated with the 2 algal species after 4, 8, 12, and 16 wk of degradation. Data are means $(+1 \mathrm{SD}, \mathrm{n}=3)$

Table 1), which ranged from -15.0 to $-19.1 \%$. $\delta^{15} \mathrm{~N}$ did not differ between algal species but increased between 0 and 16 wk for $S$. latissima $(6.1 \%)$ and $C$. fragile (5.8\%) (Fig. 2c, Table 1).

The concentration of DMS(P) in degrading Codium fragile ( 1.0 to $3.3 \%$ ) was 1 to 2 orders of magnitude higher than in degrading Saccharina latissima (0.03 to $0.1 \%$ ) and decreased significantly between 4 and 16 wk $\left(F_{3,8}=9.22, \mathrm{p}=0.006\right.$, Tukey's HSD: $4>12=$ 16 wk) (Fig. 2d).

\section{Macrofaunal communities}

Macrofauna colonized both Saccharina latissima and Codium fragile within $4 \mathrm{wk}$, but differences in faunal abundance between species varied among sampling intervals, resulting in a significant interaction between algal species and elapsed time (Fig. 3, Table 2). Macrofaunal abundance was approximately 2 and 6 times greater on $S$. latissima than on C. fragile after 4 and $8 \mathrm{wk}$, respectively, but then decreased markedly on $S$. latissima between 12 and $16 \mathrm{wk}$, when abundance no longer differed between algal species (Fig. 3, Table 2). A total of 41 and 37 taxa (14 identified to family, 4 to genus, 23 to species) were associated with degrading $S$. latissima and C. fragile, respectively, throughout the experiment (Appendix 1). Taxonomic richness did not differ between algal species, with means ranging from 12 to 20 taxa on $S$. latissima and from 12 to 15 taxa on

Table 2. Two-way ANOVA of the effect of algal species (C: Codium fragile; S: Saccharina latissima) and elapsed time $(4,8,12$, and $16 \mathrm{wk})$ on the richness (no. of species), abundance (ind. $\left.\mathrm{bag}^{-1}\right)$, evenness $\left(J^{\prime}\right)$, and diversity $\left(H^{\prime}\right)$ of macrofaunal communities associated with degrading algal samples. Tukey's pairwise comparisons were made where time or the interaction between algal species and time were significant. Lines connect non-significant subsets of treatment means: horizontal lines compare time intervals; vertical lines compare algal species when there is a significant interaction

\begin{tabular}{|c|c|c|c|c|c|}
\hline $\begin{array}{l}\text { Response } \\
\text { Factor }\end{array}$ & $\mathrm{df}$ & MS & $F$ & $\mathrm{p}$ & Pairwise \\
\hline \multicolumn{6}{|l|}{ Richness } \\
\hline Algae & 1 & 22.0 & 1.98 & 0.178 & \\
\hline Time & 3 & 36.0 & 3.24 & 0.050 & \\
\hline Time $\times$ Algae & 3 & 5.49 & 0.493 & 0.692 & \\
\hline Residual & 16 & 11.1 & & & \\
\hline \multicolumn{6}{|l|}{ Abundance } \\
\hline Algae & 1 & 2.98 & 11.3 & 0.004 & \\
\hline Time & 3 & 0.99 & 3.77 & 0.032 & \\
\hline Time $\times$ Algae & 3 & 1.23 & 4.68 & 0.016 & $\mathrm{C}: \underline{4} 812 \underline{16}$ \\
\hline & & & & & 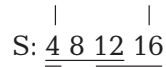 \\
\hline Residual & 16 & 0.26 & & & \\
\hline \multicolumn{6}{|l|}{ Evenness } \\
\hline Algae & 1 & 0.15 & 25.6 & $<0.001$ & \\
\hline Time & 3 & 0.11 & 18.1 & $<0.001$ & $48 \underline{1216}$ \\
\hline Time $\times$ Algae & 3 & 0.02 & 3.24 & 0.050 & \\
\hline Residual & 16 & 0.01 & & & \\
\hline \multicolumn{6}{|l|}{ Diversity } \\
\hline Algae & 1 & 0.66 & 7.10 & 0.017 & \\
\hline Time & 3 & 1.19 & 12.7 & $<0.001$ & $\underline{4} 8 \underline{1216}$ \\
\hline Time $\times$ Algae & 3 & 0.16 & 1.71 & 0.205 & \\
\hline Residual & 16 & 0.09 & & & \\
\hline
\end{tabular}


C. fragile across sampling intervals (Fig. 3, Table 2). Richness was lowest on both species at $8 \mathrm{wk}$, although the effect of time was marginally nonsignificant $(p=0.050)$ (Table 2). Indices of evenness $\left(J^{\prime}\right)$ and diversity $\left(H^{\prime}\right)$ were significantly higher for $C$. fragile than $S$. latissima and varied significantly over time, with lowest values for both species at $8 \mathrm{wk}$ (Fig. 3, Table 2).

Cluster analysis indicated $>60 \%$ similarity among macrofaunal assemblages on Saccharina latissima that degraded for 4 and $8 \mathrm{wk}$, with 1 outlier at $8 \mathrm{wk}$. In contrast, macrofaunal assemblages on Codium fragile that degraded for $4 \mathrm{wk}$ were highly variable in composition ( $<40 \%$ similarity) and distinct from samples of $S$. latissima. The similarity of samples of C. fragile increased slightly at $8 \mathrm{wk}$ ( $55 \%$ similar) but remained distinct from those of S. latissima. Macrofaunal assemblages from algae that had degraded for 12 wk were more similar in composition between and within algal species; samples of both algal species showed $>60 \%$ similarity at $16 \mathrm{wk}$. PERMANOVA detected a significant interaction between algal species and elapsed time in the composition of macrofaunal assemblages (Table 3), as differences between $S$. latissima and $C$. fragile diminished with algal degradation.

SIMPER analysis identified polychaetes of the family Capitellidae as contributing most to differences in macrofaunal assemblage between Saccharina latissima and Codium fragile and to changes over time on $S$. latissima (Appendix 2). Capitellidae were more abundant on $S$. latissima than $C$. fragile at 4,8 , and $12 \mathrm{wk}$ but were rare on both algal species at $16 \mathrm{wk}$ (Fig. 4, Table 4). The razor clam Ensis directus contributed most to differences between $S$. latissima and C. fragile at $16 \mathrm{wk}$ and to differences between time intervals in $C$. fragile, with the highest abundances observed on C. fragile at $16 \mathrm{wk}$ (Fig. 4, Table 4, Appendix 2). Relatively high abundances of amphipods of the family Gammaridae on both algal species

Table 3. Two-way permutational multivariate analysis of variance (PERMANOVA) of the effect of algal species (Codium fragile and Saccharina latissima) and elapsed time $(0,4,8,12$, and $16 \mathrm{wk})$ on overall macrofaunal community composition of degrading algal samples

\begin{tabular}{|lcccc|}
\hline Factor & df & MS & $F$ & $p$ \\
\hline Time & 3 & 0.00392 & 4.64 & 0.001 \\
Algae & 1 & 0.00261 & 3.08 & 0.001 \\
Time $\times$ Algae & 3 & 0.00187 & 2.21 & 0.002 \\
Residual & 16 & 0.0846 & & \\
\hline
\end{tabular}

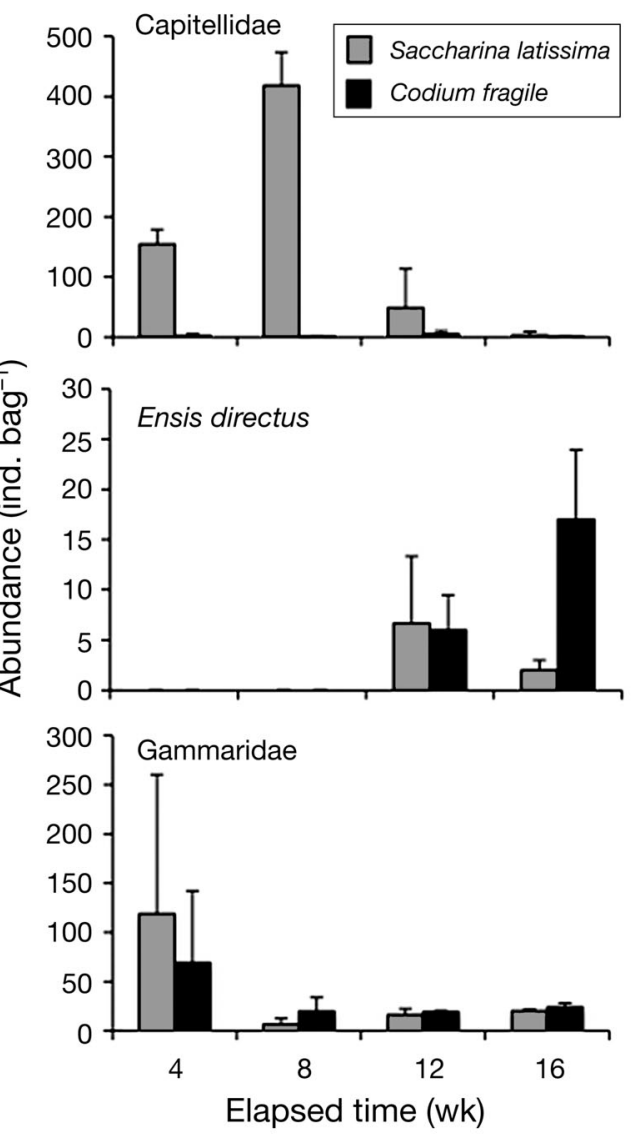

Fig. 4. Abundances of the taxa (Capitellidae, Ensis directus, and Gammaridae, as identified by SIMPER (similarity of percentages), that contributed most to differences in macrofaunal community composition on Saccharina latissima and Codium fragile after 4, 8, 12, and 16 wk of degradation, and that varied significantly over time or between algal species. Data are means (+1 SD, $\mathrm{n}=3$ )

at 4 wk contributed to differences between these samples and those that had degraded for 8,12 , and 16 wk (Fig. 4, Table 4, Appendix 2). SIMPER also identified shrimp (Mysis spp.) and a small gastropod (Lacuna vincta) as contributing to differences in community composition over the course of degradation on C. fragile (Appendix 2), but the effects of algal species and elapsed time on the abundance of each of these taxa were non-significant (Table 4).

\section{DISCUSSION}

We have shown that detached thalli of Saccharina latissima and Codium fragile differ significantly in their rate of degradation, and the manner in which biochemical composition and nutritional quality change during degradation, indicating that displace- 
Table 4. Two-way ANOVA of the effect of algal species (C: Codium fragile; S: Saccharina latissima) and elapsed time $(4,8,12$, and $16 \mathrm{wk})$ on the abundance (ind. $\left.\mathrm{bag}^{-1}\right)$ of taxa identified by SIMPER as contributing most to differences in overall macrofaunal community composition between degrading algal samples. Tukey's pairwise comparisons were made where time or the interaction between algal species and time were significant. Lines connect non-significant subsets of treatment means: horizontal lines compare time intervals; vertical lines compare algal species when there is a significant interaction

\begin{tabular}{|c|c|c|c|c|c|}
\hline $\begin{array}{l}\text { Response } \\
\text { Factor }\end{array}$ & $\mathrm{df}$ & MS & $F$ & $\mathrm{p}$ & Pairwise \\
\hline \multicolumn{6}{|l|}{ Capitellidae } \\
\hline Algae & 1 & 47.9 & 34.8 & $<0.001$ & \\
\hline Time & 3 & 8.95 & 6.50 & 0.004 & \\
\hline \multirow[t]{2}{*}{ Time $\times$ Algae } & 3 & 8.41 & 6.11 & 0.006 & C: $\underline{481216}$ \\
\hline & & & & & $\mathrm{S}: \underline{\underline{48} 1216}$ \\
\hline Residual & 16 & 1.38 & & & \\
\hline \multicolumn{6}{|l|}{ Gammaridae } \\
\hline Algae & 1 & 0.43 & 0.531 & 0.477 & \\
\hline Time & 3 & 2.94 & 3.60 & 0.037 & $\underline{4} 81216$ \\
\hline Time $\times$ Algae & 3 & 0.94 & 1.15 & 0.361 & \\
\hline Residual & 16 & 0.76 & & & \\
\hline \multicolumn{6}{|l|}{ Mysis spp. } \\
\hline Algae & 1 & 0.12 & 0.167 & 0.688 & \\
\hline Time & 3 & 0.70 & 0.994 & 0.421 & \\
\hline Time $\times$ Algae & 3 & 1.94 & 2.74 & 0.077 & \\
\hline Residual & 16 & 0.71 & & & \\
\hline \multicolumn{6}{|l|}{ Lacuna vincta } \\
\hline Algae & 1 & 0.05 & 0.0373 & 0.849 & \\
\hline Time & 3 & 0.70 & 0.568 & 0.644 & \\
\hline Algae $\times$ Time & 3 & 1.68 & 1.37 & 0.288 & \\
\hline Residual & 16 & 1.23 & & & \\
\hline \multicolumn{6}{|l|}{ Ensis directus } \\
\hline Algae & 1 & 1.33 & 6.39 & 0.022 & \\
\hline Time & 3 & 7.00 & 33.5 & $<0.001$ & \\
\hline Algae $\times$ Time & 3 & 1.16 & 5.54 & 0.008 & C: $\underline{48} \underline{1216}$ \\
\hline & & & & & $\begin{array}{lll} & \overline{|l|} \mid & \\
\mathrm{S}: 48 & 8 & 1216\end{array}$ \\
\hline Residual & 16 & 0.21 & & & \\
\hline
\end{tabular}

ment of native kelps by $C$. fragile alters the nature of detrital export from shallow subtidal areas. Degradation of $C$. fragile was delayed compared to S. latissima, resulting in a lower mass loss in C. fragile after 16 wk. The concentration of the grazing-deterrent compound DMS(P) (Van Alstyne \& Houser 2003, Lyons et al. 2010) increased slightly in C. fragile $4 \mathrm{wk}$ after transplantation, when mass loss was minimal, likely in response to a decrease in water temperature with depth (Lyons et al. 2010). Similarly, the concentration of DMS(P) in attached C. fragile at 5 to $7 \mathrm{~m}$ depth (the source of experimental thalli) increased over the course of the experiment from 2.0 to $7.0 \%$ (not shown) as temperatures decreased in the shal- lows from 23 to $7^{\circ} \mathrm{C}$. High DMS(P) concentration in $C$. fragile may have deterred consumption by macrofauna initially, but as degradation progressed, DMS(P) concentration gradually declined along with algal mass, coinciding with a change in the taxonomic composition and abundance of associated macrofauna. Live tissue from $S$. latissima had a higher $\mathrm{C} / \mathrm{N}$ ratio than $C$. fragile, and therefore a relatively low nutritional value for most consumers (Hessen 1992, Norderhaug et al. 2003). We observed a marked decrease in $\mathrm{C} / \mathrm{N}$ ratio of degrading $S$. latissima, which generally is attributed to microbial colonization and transformation (Mann 1988, Duggins \& Eckman 1997, Norderhaug et al. 2003). C/N ratio was much lower in $C$. fragile than in S. latissima and decreased minimally during degradation. This is consistent with previous work showing a higher protein content and lower $\mathrm{C} / \mathrm{N}$ of $C$. fragile relative to other brown algal species, indicating higher nutritional quality (Cruz-Rivera \& Hay 2001, Zhang et al. 2010).

Degradation did not affect $\delta^{13} \mathrm{C}$ signatures of Saccharina latissima and Codium fragile. Stephenson et al. (1986) also found no change in $\delta^{13} \mathrm{C}$ of $S$. latissima during degradation, and minimal depletion in $\delta^{13} \mathrm{C}(\sim 1 \%)$ has been reported in other macroalgal species, including the kelp Ecklonia radiata (Fenton \& Ritz 1988, Hill \& McQuaid 2009). $\delta^{15} \mathrm{~N}$ signatures of $S$. latissima and $C$. fragile became slightly enriched during degradation, likely because of microbial assimilation of $\delta^{15} \mathrm{~N}$-enriched dissolved inorganic nitrogen (DIN) (Macko \& Estep 1984). The magnitude and direction of changes in $\delta^{15} \mathrm{~N}$ during degradation vary across primary producer groups (Caraco et al. 1998, Hill \& McQuaid 2009) in response to differences in microbial community composition, the $\mathrm{C} / \mathrm{N}$ ratio of the organic substrate, and spatial variation in the $\delta^{15} \mathrm{~N}$ composition of DIN (Macko \& Estep 1984, Lehmann et al. 2002). Changes in $\delta^{15} \mathrm{~N}$ during degradation may obscure interpretation of the trophic position of consumers in stable isotope analysis of benthic food webs. For example, $\delta^{13} \mathrm{C}$ values in sea urchins collected in barrens up to $240 \mathrm{~m}$ from kelp beds indicate that drift kelp is an important food source (Kelly et al. 2012). However, these sea urchins have enriched $\delta^{15} \mathrm{~N}$ values relative to sea urchins in kelp beds, suggesting either a higher trophic position (i.e. consumption of some animal material) or greater consumption of degraded kelp.

Temperature also influences microbial activity (Tang et al. 2006, Piontek et al. 2009) and degradation rate of algal detritus (Rothausler et al. 2009). The 
degradation rates of Saccharina latissima and Codium fragile may have fluctuated with daily temperatures, which varied by 8 to $15^{\circ} \mathrm{C}$ within each of the first 4 sampling intervals. However, mean temperature was relatively constant $\left(10\right.$ to $\left.11^{\circ} \mathrm{C}\right)$ across the 4 wk intervals, and this may have obscured shorter term variation in degradation rate related to temperature during the first $12 \mathrm{wk}$ of the experiment.

Our experiment shows that detrital deposits of Codium fragile and Saccharina latissima in sedimentary habitats are rapidly colonized by a variety of macrofauna. This is consistent with previous studies suggesting that detrital material is a significant food subsidy to areas offshore of kelp beds (or forests) worldwide and an important trophic linkage between high and low productivity habitats (McLachlan 1985, Vetter \& Dayton 1999, Rodriguez 2003, Britton-Simmons et al. 2009, Krumhansl \& Scheibling 2011). Thalli of $C$. fragile degraded more slowly than those of $S$. latissima and accumulated a macrofaunal assemblage that was less abundant but more diverse than the assemblage on kelp. The diversity of associated macrofauna differed most between algal species during the first half of the experiment, when capitellid polychaetes were highly abundant on $S$. latissima, but rare or absent on $C$. fragile, resulting in a marked difference in evenness. Capitellids are highly opportunistic and non-selective feeders, and are commonly associated with food items with a high $\mathrm{C} / \mathrm{N}$ ratio (Fauchald \& Jumars 1979, Mamouridis et al. 2011). The abundance of capitellids on $S$. latissima decreased at 12 and $16 \mathrm{wk}$, coinciding with increases in diversity and evenness to similar levels as C. fragile, and increasing similarity of macrofaunal assemblages between algal species. These results concur with previous studies, indicating that changes in the detrital macrofaunal assemblage are tightly linked to changes in the $\mathrm{C} / \mathrm{N}$ ratio associated with degradation (Norderhaug et al. 2003, Cebrian \& Lartigue 2004, Van Alstyne et al. 2009). Gammarid amphipods also appear to be capable of consuming food with a lower nutritional quality. Abundance of these amphipods on both $S$. latissima and $C$. fragile was highest after 4 wk of degradation, suggesting they may be important early colonizers and facilitators of subsequent detrital breakdown. In contrast, the razor clam Ensis directus emerged on both algal species as degradation progressed, possibly in response to increased quantities of degraded algal particles, and was abundant on C. fragile at 16 wk.

Live and attached Codium fragile supports a more diverse community of epifauna and epiphytes than native kelps (Schmidt \& Scheibling 2006, 2007) and other species of brown, red, and green algae (Jones \& Thornber 2010, Lutz et al. 2010). This has been attributed to the highly branched morphology of $C$. fragile, which may provide more shelter from predators, greater surface area for attachment (Schmidt \& Scheibling 2006, Drouin et al. 2011), and higher sedimentation rates (Schmidt \& Scheibling 2007) compared to native species. Structural complexity also may influence detrital macrofaunal assemblages immediately following deposition of intact thalli but likely decreases in importance relative to nutritional quality and palatability as thallus structure breaks down. Differences in macrofaunal composition between attached thalli of $C$. fragile and Saccharina latissima in Nova Scotia are explained by lower abundances of gastropods and asteroids, and higher abundances of amphipods, harpacticoid copepods, and the nudibranch Placida dendritica on C. fragile (Schmidt \& Scheibling 2006). These differences are not consistent with those that characterize degrading thalli of these species, indicating that different factors regulate the species-specific colonization patterns of live and detrital macroalgae.

In Nova Scotia, rates of fragmentation and dislodgement of Codium fragile are greatest in fall and early winter, resulting in an increased deposition of this detrital material at these times (Begin \& Scheibling 2003, D'Amours \& Scheibling 2007). However, the timing of fragmentation and attendant production of detritus by stands of $C$. fragile varies among regions and occurs throughout the year in some areas (Trowbridge 1996, 1998). Thalli of $C$. fragile used for this experiment were collected during the seasonal minimum in DMSP production coincident with high water temperatures (Lyons et al. 2010). In regions were fragmentation occurs during periods of low temperature in winter and spring (Fralick \& Matheison 1973, Trowbridge 1993), the DMSP content of detrital fragments is likely higher, which may result in a greater deterrent effect on potential consumers and slower degradation rate than observed in our study.

Adult ( $>20 \mathrm{~mm}$ test diameter) sea urchins Strongylocentrotus droebachiensis were absent on the sandy bottom during our experiment. Juvenile sea urchins were common in the adjacent kelp bed (authors' pers. obs.), and small juveniles $(<10 \mathrm{~mm})$ occasionally were found on Saccharina latissima and Codium fragile throughout the $16 \mathrm{wk}$ experiment. Where large sea urchins are abundant, they can consume drift algal deposits before substantial degradation occurs (Lyons \& Scheibling 2008, Britton-Simmons et al. 2009). Consumption by sea urchins will greatly 
accelerate the degradation process, as large fragments of algae are reduced to small ( 2.4 mm diameter) fecal particles (Sauchyn \& Scheibling 2009a). These feces are of higher nutritional quality (lower $\mathrm{C} / \mathrm{N}$ ratio) than fresh algal material (Sauchyn \& Scheibling 2009b), and degrade more rapidly than fresh kelp (Sauchyn \& Scheibling 2009b). Our cages excluded other large detritivores and predators of macrofauna, such as lobsters and crabs, which also may contribute to the degradation of algal thalli and influence the structure of associated macrofaunal assemblages.

Our findings are consistent with previous studies that have documented shifts in macrofaunal assemblages on mudflats in response to changing detrital resources following algal species invasions (Bishop et al. 2010, Taylor et al. 2010), indicating that the effects of algal invaders can extend beyond the introduced habitat to those linked via the transfer of detrital material. Given the trophic importance of detrital pathways (Cebrian 1999, Cebrian \& Lartigue 2004), these studies demonstrate that introductions of algal species can have more far-reaching impacts than previously considered.

Acknowledgements. We thank J. Lindley, C. Feehan, K. Filbee-Dexter for field assistance, and J. Bryk and F. Francis for laboratory assistance. We are particularly grateful to $\mathrm{N}$. Kamenos and H. Burdett at the University of Glasgow for analysis of DMS(P). J. Kelly provided statistical advice and helpful comments on a previous draft of the manuscript. This research was funded by a Discovery Grant and a Strategic Networks Grant (Canadian Healthy Oceans Network) to R.E.S. K.A.K. was supported by a Dalhousie Scholarship.

\section{LITERATURE CITED}

Anderson MJ (2001) A new method for non-parametric multivariate analysis of variance. Austral Ecol 26:32-46

Anderson MJ (2004) PERMDISP: a FORTRAN computer program for permutational analysis of multivariate dispersions (for any two-factor ANOVA design) using permutation tests. Dept of Statistics, University of Auckland, Auckland

> Begin C, Scheibling RE (2003) Growth and survival of the invasive green alga Codium fragile ssp. tomentosoides in tide pools on a rocky shore in Nova Scotia. Bot Mar 46: 404-412

Bird CJ, Dadswell MJ, Grund DW (1993) First record of the potential nuisance alga Codium fragile ssp. tomentosoides (Chlorophyta, Caulerpales) in Atlantic Canada. Proc Nova Scotia Inst Sci 40:11-17

Bishop MJ, Coleman MA, Kelaher BP (2010) Cross-habitat impacts of species decline: response of estuarine sediment communities to changing detrital resources. Oecologia 163:517-525

Bouillon S, Koedam N, Raman AV, Dehairs F (2002) Primary producers sustaining macro-invertebrate communities in intertidal mangrove forests. Oecologia 130:441-448
Britton-Simmons KH, Foley G, Okamoto D (2009) Spatial subsidy in the subtidal zone: utilization of drift algae by a deep subtidal sea urchin. Aquat Biol 5:233-243

Bustamante RH, Branch GM (1996) The dependence of intertidal consumers on kelp-derived organic matter on the west coast of South Africa. J Exp Mar Biol Ecol 196: $1-28$

Bustamante RH, Branch GM, Eekhout S (1995) Maintenance of an exceptional intertidal grazer biomass in South Africa: subsidy by subtidal kelps. Ecology 76:2314-2329

Caraco NF, Lampman G, Cole JJ, Limburg KE, Pace ML, Fischer D (1998) Microbial assimilation of DIN in a nitrogen rich estuary: implications for food quality and isotope studies. Mar Ecol Prog Ser 167:59-71

- Carlton JT, Scanlon JA (1985) Progression and dispersal of an introduced alga: Codium fragile ssp. tomentosoides (Chlorophyta) on the Atlantic coast of North America. Bot Mar 28:155-165

Cebrian J (1999) Patterns in the fate of production in plant communities. Am Nat 154:449-468

Cebrian J, Lartigue J (2004) Patterns of herbivory and decomposition in aquatic and terrestrial ecosystems. Ecol Monogr 74:237-259

Chapman ARO (1981) Stability of sea urchin dominated barren grounds following destructive grazing of kelp in St. Margret's Bay, eastern Canada. Mar Biol 62:307-311

- Chapman ARO (1984) Reproduction, recruitment and mortality in two species of Laminaria in Southwest Nova Scotia. J Exp Mar Biol Ecol 78:99-109

Chapman AS, Scheibling RE, Chapman ARO (2002) Species introductions and changes in marine vegetation of Atlantic Canada. In: Claudi R, Nantel P, Muckle-Jeffs E (eds) Alien invaders in Canada's waters, wetlands and forests. Natural Resources Canada, Canadian Forest Service Science Branch, Ottawa, p 133-1484

Clarke KR, Gorley RN (2006) PRIMER v6: user manual/tutorial. PRIMER-E, Plymouth

$>$ Cruz-Rivera E, Hay ME (2001) Macroalgal traits and the feeding and fitness of an herbivorous amphipod: the roles of selectivity, mixing, and compensation. Mar Ecol Prog Ser 218:249-266

> D'Amours O, Scheibling RE (2007) Effects of wave exposure on morphology, attachment strength and survival of the invasive green alga Codium fragile ssp. tomentosoides. J Exp Mar Biol Ecol 351:129-142

> Drouin A, McKindsey CW, Johnson LE (2011) Higher abundance and diversity in faunal assemblages with the invasion of Codium fragile ssp. fragile in eelgrass meadows. Mar Ecol Prog Ser 424:105-117

$>$ Duggins DO, Eckman JE (1997) Is kelp detritus a good food for suspension feeders? Effects of kelp species, age and secondary metabolites. Mar Biol 128:489-495

$>$ Duggins DO, Simenstad CA (1989) Magnification of secondary production by kelp detritus in coastal marine ecosystems. Science 245:170-173

Fauchald K, Jumars PA (1979) The diet of worms: a study of polychaete feeding guilds. Oceanogr Mar Biol Annu Rev 17:193-284

Fenton G, Ritz D (1988) Changes in carbon and hydrogen stable isotope ratios of macroalgae and seagrass during decomposition. Estuar Coast Shelf Sci 26:429-436

- Filbee-Dexter K, Scheibling RE (2012) Hurricane-mediated defoliation of kelp beds and pulsed delivery of kelp detritus to offshore sedimentary habitats. Mar Ecol Prog Ser 455:51-64 
Fralick RA, Matheison AC (1973) Ecological studies of Codium fragile in New England, USA. Mar Biol 19: $127-132$

Hessen DO (1992) Nutrient limitation of zooplankton production. Am Nat 140:799-814

Hill JM, McQuaid CD (2009) Variability in the fractionation of stable isotopes during degradation of two intertidal red algae. Estuar Coast Shelf Sci 82:397-405

Iken K, Amsler CD, Amsler MO, McClintock JB, Baker BJ (2009) Field studies on deterrent properties of phlorotannins in Antacrtic brown algae. Bot Mar 52:647-657

> Johnson CR, Mann KH (1986) The importance of plant defense abilities to the structure of subtidal seaweed communities: the kelp Laminaria longicruris de la Pylaie survives grazing by the snail Lacina vincta (Montagu) at high population densities. J Exp Mar Biol Ecol 97: 231-267

> Jones E, Thornber CS (2010) Effects of habitat-modifying invasive macroalgae on epiphytic algal communities. Mar Ecol Prog Ser 400:87-100

Kelly JR, Krumhansl KA, Scheibling RE (2012) Drift algal subsidies to sea urchins in low-productivity habitats. Mar Ecol Prog Ser 452:145-157

Krumhansl KA, Scheibling RE (2011) Detrital production in Nova Scotian kelp beds: patterns and processes. Mar Ecol Prog Ser 421:67-82

> Lehmann MF, Bernasconi SM, Barbieri A, McKenzie JA (2002) Preservation of organic matter and alteration of its carbon and nitrogen isotopic composition during simulated and in situ early sedimentary diagenesis. Geochim Cosmochim Acta 66:3573-3584

> Lutz ML, Davis AR, Minchinton TE (2010) Non-indigenous macroalga hosts different epiphytic assemblages to conspecific natives in southeast Australia. Mar Biol 157: 1095-1103

> Lyons DA, Scheibling RE (2008) Context-dependent survival of the invasive seaweed Codium fragile spp. tomentosoides in a kelp bed and urchin barren habitat off Nova Scotia. Aquat Biol 2:17-27

> Lyons DA, Van Alstyne KL, Scheibling RE (2007) Antigrazing activity and seasonal variation of dimethylsulfoniopropionate-associated compounds in the invasive alga Codium fragile spp tomentosoides. Mar Biol 153: 179-188

Lyons DA, Scheibling RE, Van Alstyne KL (2010) Spatial and temporal variation in DMSP content in the invasive seaweed Codium fragile spp. fragile: effects of temperature, light and grazing. Mar Ecol Prog Ser 417:51-61

Macko S, Estep M (1984) Microbial alteration of stable nitrogen and carbon isotopic compositions of organic matter. Org Geochem 6:787-790

Mamouridis V, Cartes JE, Parra S, Fanelli E, Salinas JIS (2011) A temporal analysis on the dynamics of deep-sea macrofauna: influence of environmental variability off Catalonia coasts (western Mediterranean). Deep-Sea Res 158:323-337

Mann KH (1982) Kelp, sea urchins and predators: a review of strong interactions in rocky subtidal systems of eastern Canada. J Sea Res 16:414-423

Mann KH (1988) Production and use of detritus in various freshwater, estuarine, and coastal marine ecosystems. Limnol Oceanogr 33:910-930

> McDevit DC, Saunders GW (2010) A DNA barcode examination of the Laminariaceae (Phaeophyceae) in Canada reveals novel biogeographical and evolutionary insights.
Phycologia 49:235-248

McLachlan A (1985) The biomass of macro- and interstitial fauna on clean and wrack-covered beaches in western Australia. Estuar Coast Shelf Sci 21:587-599

> Norderhaug KM, Fredriksen S, Nygaard K (2003) Trophic importance of Laminaria hyperborean to kelp forest consumers and the importance of bacterial degradation to food quality. Mar Ecol Prog Ser 255:135-144

Paul VJ (ed) (1992) Ecological roles of marine natural products. Comstock Publishing Associates, Ithaca, NY

> Peterson BJ, Fry B (1987) Stable isotopes in ecosystem studies. Annu Rev Ecol Syst 18:293-320

> Piontek J, Handel N, Langer G, Wohlers J, Riebesell U, Engel A (2009) Effects of rising temperature on the formation and microbial degradation of marine diatom aggregates. Aquat Microb Ecol 54:305-318

$>$ Provan J, Booth D, Todd NP, Beatty GE, Maggs CA (2008) Tracking biological invasions in space and time: elucidating the invasive history of the green alga Codium fragile using old DNA. Div Dist 14:343-354

Rodriguez SR (2003) Consumption of drift kelp by intertidal populations of the sea urchin Tetrapygus niger on the central Chilean coast: possible consequences at different ecological levels. Mar Ecol Prog Ser 251:141-151

Rothausler E, Gomez I, Hinojosa IA, Karsten U, Tala F, Thiel $M$ (2009) Effect of temperature and grazing on growth and reproduction of floating Macrocystis spp. (Phaeophyceae) along a latitudinal gradient. J Phycol 45: 547-559

Sauchyn LK, Scheibling RE (2009a) Fecal production by sea urchins in native and invaded algal beds. Mar Ecol Prog Ser 396:35-48

Sauchyn LK, Scheibling RE (2009b) Degradation of sea urchin feces in a rocky subtidal ecosystem: implications for nutrient cycling and energy flow. Aquat Biol 6:99-108

Scheibling RE, Gagnon P (2006) Competitive interactions between the invasive green alga Codium fragile ssp. tomentosoides and native canopy-forming seaweeds in Nova Scotia (Canada). Mar Ecol Prog Ser 325:1-14

Scheibling RE, Hennigar AW, Balch T (1999) Destructive grazing, epiphytism, and disease: the dynamics of sea urchin-kelp interactions in Nova Scotia. Can J Fish Aquat Sci 56:2300-2314

Schmidt AL, Scheibling RE (2005) Population dynamics of an invasive green alga, Codium fragile spp tomentosoides, in tidepools on a rocky shore in Nova Scotia, Canada. Ecoscience 12:403-411

> Schmidt AL, Scheibling RE (2006) A comparison of epifauna and epiphytes on native kelps (Laminaria species) and an invasive alga (Codium fragile spp. tomentosoides) in Nova Scotia, Canada. Bot Mar 49:315-330

Schmidt AL, Scheibling RE (2007) Effects of native and invasive macroalgal canopies on composition and abundance of mobile benthic macrofauna and turf-forming algae. J Exp Mar Biol Ecol 341:110-130

> Stephenson RL, Tan FC, Mann KH (1986) Use of stable carbon isotope ratios to compare plant material and potential consumers in a seagrass bed and a kelp bed in Nova Scotia, Canada. Mar Ecol Prog Ser 30:1-7

Tala F, Edding M (2007) First estimates of productivity in Lessonia trabeculata and Lessonia nigrescens (Phaeophyceae, Laminariales) from the southeast Pacific. Phycol Res 55:66-79

Tang KW, Freund CS, Schweitzer CL (2006) Occurrence of copepod carcasses in the lower Chesapeake Bay and 
their decomposition by ambient microbes. Estuar Coast Shelf Sci 68:499-508

Taylor SL, Bishop MJ, Kelager BP, Glasby TM (2010) Impacts of detritus from the invasive algae Caulerpa taxifolia on a soft sediment community. Mar Ecol Prog Ser 420:73-81

Tenore KR, Hanson RB (1980) Availability of detritus of different types and ages to a polychaete macroconsumer Capitella capitata. Limnol Oceanogr 25:553-558

Trowbridge CD (1993) Interactions between an ascoglossan sea slug and its green algal host: branch loss and role of epiphytes. Mar Ecol Prog Ser 101:263-272

Trowbridge CD (1996) Introduced versus native subspecies of Codium fragile: How distinctive is the invasive subspecies tomentosoides? Mar Biol 126:193-204

Trowbridge CD (1998) Ecology of the green macroalga Codium fragile (Suringar) Hariot 1889: invasive and noninvasive subspecies. Oceanogr Mar Biol Annu Rev 36: $1-64$

Tzetlin AB, Mokievsky VO, Melnikov AN, Saphonov MV, Simdyanov TG, Ivanov IE (1997) Fauna associated with detached kelp in different types of subtidal habitats of the White Sea. Hydrobiologia 355:91-100

Van Alstyne KL, Houser LT (2003) Dimethylsulfide release during macroinvertebrate grazing and its role as an activated chemical defense. Mar Ecol Prog Ser 250:175-181

Van Alstyne KL, Puglisi MP (2007) DMSP in marine macroalgae and macroinvertebrates: distribution, function, and ecological impacts. Aquat Sci 69:394-402
Van Alstyne KL, Wolfe GV, Freidenburg TL, Neill A, Hicken C (2001) Activated defense system in marine macroalgae: evidence for an ecological role for DMSP cleavage. Mar Ecol Prog Ser 213:53-65

> Van Alstyne KL, Pelletreau KN, Kirby A (2009) Nutritional preferences override chemical defenses in determining food choice by a generalist herbivore, Littorina sitkana. J Exp Mar Biol Ecol 379:85-91

> Vetter EW, Dayton PK (1998) Macrofaunal communities within and adjacent to a detritus-rich submarine canyon system. Deep-Sea Res II 45:25-54

> Vetter EW, Dayton PK (1999) Organic enrichment by macrophyte detritus, and abundance patterns of megafaunal populations in submarine canyons. Mar Ecol Prog Ser 186:137-148

Watanabe S, Metaxas A, Scheibling RE (2009) Dispersal potential of the invasive green alga Codium fragile ssp. fragile. J Exp Mar Biol Ecol 38:114-125

Watanabe S, Scheibling RE, Metaxas A (2010) Contrasting patterns of spread in interacting invasive species: Membranipora membranacea and Codium fragile off Nova Scotia. Biol Invasions 12:2329-2342

Wernberg T, Vanderklift MA, How J, Lavery PS (2006) Export of detached macroalgae from reefs to adjacent seagrass beds. Oecologia 147:692-701

Zhang J, Shang D, Wang W, Jiang Z, Xue S, Fang J (2010) The potential for utilizing fouling macroalgae as feed for abalone Haliotis discus hannai. Aquacult Res 41: 1770-1777

Appendix 1. Macrofaunal taxa on samples of degrading Saccharina latissima and Codium fragile. +: taxon present

\begin{tabular}{|c|c|c|c|c|c|}
\hline Taxon & S. latissima & C. fragile & Taxon & S. latissima & C. fragile \\
\hline Arthropoda & & & Mollusca (continued) & & \\
\hline Mysis spp. & + & + & Margarites groenlandicus & + & + \\
\hline Gammaridae & + & + & Ischnochiton ruber & + & + \\
\hline Caprellidae & + & + & Onchidoris bilamellata & + & + \\
\hline Hyperiidae & + & + & Ensis directus & + & + \\
\hline Pagurus acadianus & + & + & Placida dendritica & + & \\
\hline Cancer irroratus & + & + & Turbinilla interrupta & + & + \\
\hline Libinia emarginata & + & & Haminoea solitaria & + & + \\
\hline Bodotriidae & + & + & Euspira heros & + & + \\
\hline Asellidae & + & + & Placopecten magellanicus & + & + \\
\hline Echinodermata & & & Annelida & & \\
\hline Ophiopholis aculeata & + & + & Capitellidae & & \\
\hline Amphiolis squamata & + & + & Nereididae & + & + \\
\hline Stronglyocentrotus droebachiensis & + & + & Sabellidae & + & + \\
\hline Asterias spp. & + & & Polynoidae & + & + \\
\hline Henricia sanguinolenta & + & + & Dorvilleidae & + & + \\
\hline Mollusca & & & Phyllodocida & + & + \\
\hline Littorina spp. & + & + & Platyhelminthes & & \\
\hline Lacuna vincta & + & + & Bdellouridae & + & + \\
\hline Musculus spp. & + & + & Leptoplanidae & + & + \\
\hline Modiolus modiolus & + & + & Nemertea & & \\
\hline Anomia simplex & + & + & Cephalothrichidae & + & \\
\hline Nucella lapillus & + & + & Chordata & & \\
\hline Buccinum undatum & + & + & Pholis gunnellus & + & + \\
\hline Crenella glandula & + & + & & & \\
\hline
\end{tabular}


Appendix 2. Pairwise Bray-Curtis dissimilarities between macrofaunal communities associated with samples of Saccharina latissima (S) and Codium fragile (C), after 4, 8, 12, and 16 wk of degradation, from SIMPER analysis of square-roottransformed abundance data. Only taxa with dissimilarities $>2.5$ are shown

\begin{tabular}{|c|c|c|c|c|c|}
\hline \multirow{2}{*}{$\begin{array}{l}\text { Comparison } \\
\text { Taxon }\end{array}$} & \multicolumn{2}{|c|}{ Dissimilarity } & \multirow{2}{*}{$\begin{array}{l}\text { Comparison } \\
\text { Taxon }\end{array}$} & \multicolumn{2}{|c|}{ Dissimilarity } \\
\hline & Avg. & Cum. \% & & Avg. & Cum. \% \\
\hline C4 vs. S4 & & 53.8 & C4 vs. C16 & & 53.8 \\
\hline Capitellidae & 11.3 & 20.7 & Ensis directus & 5.0 & 9.4 \\
\hline Gammaridae & 5.9 & 31.7 & Gammaridae & 4.8 & 18.3 \\
\hline Polynoidae & 3.2 & 37.6 & Nerididae & 3.5 & 24.8 \\
\hline Phyllodocida & 3.0 & 43.2 & Crenella glandula & 3.4 & 31.1 \\
\hline C8 vs. S8 & & 63.8 & Lacuna vincta & 3.0 & 36.6 \\
\hline Capitellidae & 25.1 & 39.3 & Amphiolis squamata & 2.7 & 41.6 \\
\hline Polynoidae & 4.1 & 45.8 & C8 vs. C12 & & 49.3 \\
\hline Mysis spp. & 4.1 & 52.2 & Mysis spp. & 5.0 & 10.2 \\
\hline C12 vs. S12 & & 39.8 & Ensis directus & 3.6 & 17.6 \\
\hline Capitellidae & 6.4 & 16.1 & Nerididae & 3.6 & 25.0 \\
\hline Nerididae & 3.1 & 23.9 & Amphiolis squamata & 3.5 & 32.1 \\
\hline Strongylocentrotus droebachiensis & 2.6 & 30.3 & Polynoidae & 3.3 & 38.9 \\
\hline C16 vs. S16 & & 42.4 & Strongylocentrotus droebachiensis & 3.1 & 45.1 \\
\hline Ensis directus & 3.4 & 8.0 & Asellidae & 2.8 & 50.7 \\
\hline Lacuna vincta & 2.9 & 14.9 & C8 vs. C16 & & 54.9 \\
\hline Crenella glandula & 2.7 & 21.2 & Ensis directus & 5.8 & 10.6 \\
\hline C4 vs. C8 & & 52.9 & Mysis spp. & 4.3 & 18.4 \\
\hline Gammaridae & 5.9 & 11.1 & Crenella glandula & 4.2 & 26.0 \\
\hline Nerididae & 3.6 & 18.0 & Modiolus modiolus & 4.2 & 33.6 \\
\hline Mysis spp. & 3.5 & 24.5 & Lacuna vincta & 3.5 & 40.0 \\
\hline Amphiolis squamata & 3.4 & 30.9 & Anomia simplex & 2.7 & 44.9 \\
\hline Polynoidae & 3.3 & 37.1 & Polynoidae & 2.6 & 49.6 \\
\hline Lacuna vincta & 3.0 & 42.7 & Nerididae & 2.5 & 54.1 \\
\hline C4 vs. C12 & & 52.3 & C12 vs. C16 & & 39.0 \\
\hline Gammaridae & 5.4 & 10.4 & Lacuna vincta & 3.0 & 7.6 \\
\hline Nerididae & 4.4 & 18.7 & Modiolus modiolus & 2.6 & 14.3 \\
\hline Amphiolis squamata & 4.0 & 26.3 & Strongylocentrotus droebachiensis & 2.5 & 20.8 \\
\hline Ensis directus & 3.1 & 32.3 & Anomia simplex & 2.5 & 27.1 \\
\hline Strongylocentrotus droebachiensis & 2.7 & 37.4 & & & \\
\hline S4 vs. S8 & & 44.5 & S8 vs. $\mathrm{S} 12$ & & 56.2 \\
\hline Capitellidae & 7.2 & 16.1 & Capitellidae & 16.7 & 29.8 \\
\hline Gammaridae & 6.7 & 31.2 & Polynoidae & 3.6 & 36.2 \\
\hline Mysis spp. & 3.3 & 38.7 & Buccinum undatum & 3.2 & 42.0 \\
\hline Polynoidae & 2.6 & 44.4 & Lacuna vincta & 2.6 & 46.7 \\
\hline S4 vs. S12 & & 43.4 & Ensis directus & 2.6 & 51.3 \\
\hline Capitellidae & 7.2 & 16.6 & S8 vs. S16 & & 63.8 \\
\hline Gammaridae & 5.7 & 29.6 & Capitellidae & 22.3 & 35.0 \\
\hline Mysis spp. & 2.5 & 35.3 & Polynoidae & 3.9 & 41.0 \\
\hline S4 vs. S16 & & 50.6 & Buccinum undatum & 3.5 & 46.5 \\
\hline Gammaridae & 5.3 & 10.4 & Mysis spp. & 2.9 & 51.0 \\
\hline Amphiolis squamata & 3.1 & 16.5 & S12 vs S16 & & 37.6 \\
\hline Lacuna vincta & 3.1 & 22.7 & Capitellidae & 6.4 & 17.1 \\
\hline Nerididae & 2.5 & 27.6 & Nerididae & 2.7 & 24.3 \\
\hline Buccinum undatum & 2.5 & 32.5 & & & \\
\hline
\end{tabular}

Editorial responsibility: Laura Airoldi, Ravenna, Italy
Submitted: June 29, 2011; Accepted: February 13, 2012 Proofs received from author(s): May 8, 2012 